C2020. Licensed under the Creative Commons Attribution-NonCommercial-NoDerivatives 4.0 International http://creativecommons.org/about/downloads

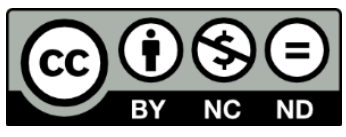

DOI of final article - https://doi.org/10.1016/j.ecoenv.2020.110392 


\title{
A study into the species sensitivity of green algae towards imidazolium-based ionic liquids using flow cytometry
}

\author{
Yun Deng ${ }^{\mathrm{a}, \mathrm{b}}$, Ian Beadham ${ }^{\mathrm{c}}$, Hongyan Ren ${ }^{\mathrm{a}, \mathrm{b}}$, Mengmeng Ji ${ }^{\mathrm{a}, \mathrm{b}}$, Wenquan Ruan ${ }^{\mathrm{a}, \mathrm{b}, *}$, \\ ${ }^{a}$ School of Environment and Civil Engineering, Jiangnan University, Wuxi 214122, China \\ b Jiangsu Key Laboratory of Anaerobic Biotechnology, Wuxi 214122, China \\ ${ }^{c}$ School of Pharmacy and Chemistry, Kingston University, Kingston upon Thames, KT1 2EE, UK
}

\begin{abstract}
The sensitivity of individual organisms towards toxic agents is an important indicator of environmental pollution. However, organism-specific quantification of sensitivity towards pollutants remains a challenge. In this study, we determined the sensitivity of Chlorella vulgaris (C. vulgaris) and Scenedesmus quadricauda (S. quadricauda) towards three ionic liquids (ILs), 1-alkyl-3-methyl-imidazolium chlorides $\left[\mathrm{C}_{\mathrm{n}} \operatorname{mim}\right][\mathrm{Cl}](\mathrm{n}=4,6,8)$. We kept all external parameters constant to identify the biotic parameters responsible for discrepancies in species sensitivity, and used flow cytometry to determine four conventional endpoints to characterise cell viability and cell vitality. Our results demonstrate that after exposure to the ILs, cell proliferation was inhibited in both species. At the same time, the cell size, complexity and membrane permeability of both algae also increased. However, while Chl $a$ synthesis by $S$. quadricauda was inhibited, that of $C$. vulgaris was enhanced. S. quadricauda has evolved a metabolic defense that can counteract the decreased esterase activity that has been shown to occur in the presence of ILs.
\end{abstract}


While it is likely that $S$. quadricauda was less sensitive than $C$. vulgaris to the ILs because of this metabolic defense, this alga may also exhibit better membrane resistance towards ILs.

Keywords: species sensitivity; toxic effect; ionic liquid; Chlorella vulgaris; Scenedesmus quadricauda

\section{Introduction}

Large-scale applications of ionic liquids (ILs), especially imidazolium-based ILs, are anticipated to increase in the near future (Chatel et al., 2017) within a variety of domains, including organic synthesis and (bio)catalysis, electrochemistry, analytical chemistry, separation technology, nanotechnology, renewable resource utilization, and functional fluids (e.g. lubricants, heat transfer fluids, corrosion inhibitors) (Bubalo et al., 2014). Nevertheless, the rapid growth in production and application of ILs will inevitably result in their discharge into environment (Torrecilla et al., 2009; Abramenko et al., 2020) through various pathways, such as accidental spills, leaching of landfill sites and wastewater discharge (Liu et al., 2015 a). An ecological risk assessment (ERA) of their effect on aquatic life is therefore essential (Thamke et al., 2017). In an ERA, determination of toxicity, expressed as an $\mathrm{EC}_{50}$ (the half-maximal effective concentration) is the approach that is most often employed, but establishing the chronic toxic effects of the pollutant on organisms represents a more sophisticated level of analysis (Wen et al., 2018; Zhang et al., 2017). The sensitivity of a diversity of species towards environmental contaminants is another 
important factor when carrying out an ERA (Barron et al., 2012), in order to avoid either "insufficient" or "excessive" assessment (Zhang et al., 2017; Park et al., 2018). Nevertheless, in spite of their importance, the latter two fields are frequently disregarded.

Since algae are an important part of the aquatic ecosystem, and provide a rapid and sensitive response to toxins (Pham et al., 2010; Moro et al., 2012), numerous reports have determined the $\mathrm{EC}_{50}$ and/or described the toxicity effects of ILs towards algae. Because they comprise a highly diverse group of photosynthetic eukaryotes, spanning up to 15 phyla, the sensitivities of algae towards toxins can vary widely. The $\mathrm{EC}_{50}$ value of a single IL towards diverse species may differ by several orders of magnitude (Kulacki et al., 2008). For example, the $96 \mathrm{~h} \mathrm{EC} \mathrm{E}_{50}$ values for $\left[\mathrm{C}_{4} \mathrm{mim}\right][\mathrm{Br}]$ towards Scenedesmus quadricauda (S. quadricauda) and Chlamydomonas reinhardtii are $22 \mu \mathrm{M}$ and $4898 \mu \mathrm{M}$, respectively. The $72 \mathrm{~h} \mathrm{EC}_{50}$ values for $\left[\mathrm{C}_{4} \mathrm{mim}\right][\mathrm{Cl}]$ towards Scenedesmus vacuolatus and Chlorella vulgaris (C. vulgaris) are $140 \mu \mathrm{M}$ and $1026 \mu \mathrm{M}$, respectively (Petkovic et al., 2011). Furthermore, the toxic effects may present in a variety of ways, including growth inhibition (Hu et al., 2013), membrane damage and membrane disruption (Chen et al., 2014), changes in morphology and structure (Liu et al., 2015 b), or abnormalities in photosynthesis (Deng et al., 2015) and metabolism (Chen et al., 2014).

It is widely recognized that discrepancies in species sensitivity are a natural consequence of interspecies variation in cell cycle, morphology, size, pigment profile and membrane morphology (Stulik et al., 2000). In addition to these innate, 
biotic factors, the sensitivity of a species to contaminants is also dependent on external abiotic parameters. It has been demonstrated that changes to the conditions of an assay, such as initial cell density and salinity of the culture medium, can lead to distinct differences in sensitivity (Tsarpali et al., 2016). In addition, for ILs, less predictable abiotic parameters, such as the diversity of IL forms in water, potential interference of ILs with the culture medium tested and IL absorption to vessel walls, might also lead to differing toxic effects (Stulik et al., 2000). In this context, the determination of species sensitivity continues to pose a significant challenge. However, if all external, abiotic parameters were to remain constant, then any possible biotic parameters responsible for discrepancies in species sensitivity could be identified.

In this study, we compared the physiological response of two algal species against 1-alkyl-3-methyl-imidazolium chlorides $\left[\mathrm{C}_{\mathrm{n}} \operatorname{mim}\right][\mathrm{Cl}](\mathrm{n}=4,6$ or 8$)$, under nearly the same assay conditions, while varying the concentration of IL tested, which resulted in around $10 \%-90 \%$ inhibition of cell density in a pre-experiment. [ $\mathrm{C}_{\mathrm{n}} \mathrm{mim}$ ] are representative cations of the imidazolium family that are regularly used in synthetic, catalytic, biomechanical, degradative, and analytical applications (Habibul et al., 2020). The anion, $\mathrm{Cl}^{-}$, was selected to represent hydrophilic ILs since it shows no intrinsic toxicity effect (Mena, 2020; Matzke et al., 2007). As test organisms, we chose $C$. vulgaris and $S$. quadricauda, which are the two major algae in the fresh water environment of China. The cell walls of both species are composed primarily of cellulose, and chlorophyll $a$ is their main photosynthetic pigment. The same 
conditions (illumination, photoperiod, initial inoculum and nutrient concentration) were used in all assays for both species, in order to avoid discrepancies arising from the experimental conditions. We used flow cytometry (FCM), a relatively new technique in toxicity studies of ILs, to determine four conventional endpoints that characterise cell viability (capacity for growth) and cell vitality (manifestation of life). A preliminary identification of the biotic factors responsible for varying species sensitivity towards ILs is given that will help to inform future ERA studies into the environmental risk posed by these polar solvents.

\section{Materials and methods}

\subsection{Reagents}

The ionic liquids were purchased from Shanghai Chengjie Chemical Co. Ltd (China). IL purity in terms of the cation was $>95 \%$, as determined by ${ }^{1} \mathrm{H}$ NMR (Bruker AV500) while the purity of the anion was also > 95\% by ion chromatography (Metrohm, Switzerland). The dyes fluorescein diacetate (FDA) and propidium iodide (PI) were purchased from the Sigma-Aldrich Chemical Co. C. vulgaris (FACHB-71) and S. quadricauda (FACHB-1297) were purchased from the Freshwater Algae Culture Collection of the Institute of Hydrobiology, Chinese Academy of Sciences. The water used in this study was deionized, and came from an ultra-pure water machine (EPED-20TH, China).

\subsection{Algal culture and IL exposure}


Water and materials to come into contact with the algae were first sterilised under $0.1 \mathrm{MPa}$ pressure at $121{ }^{\circ} \mathrm{C}$ for $30 \mathrm{mins}$, and all operations were carried out in a biosafety cabinet (ESCO AC2-4S1). Algae in the log phase of growth were inoculated in $100 \mathrm{ml}$ portions of freshly sterilized standard BG11 medium (Ma et al., 2010) within $250 \mathrm{~mL}$ Erlenmeyer flasks, in order to obtain an initial cell density of $1 \times 10^{5}$ cells $\mathrm{mL}^{-1}$.

All ILs were completely miscible with water and stock solutions of each IL at 2 $\mathrm{g} / \mathrm{L}$ were prepared. The stock solutions were dispensed into flasks of the medium, to make up the final IL concentrations $\left(C_{I L}\right)$ represented in Table 1, resulting in around $10 \%-90 \%$ inhibition of cell density in a pre-experiment.

Table 1 Exposure concentrations of ILs $\left(C_{I L} / \mathrm{mg} . \mathrm{L}^{-1}\right)$ on algae.

\begin{tabular}{llll}
\hline & {$\left[\mathrm{C}_{4} \mathrm{mim}\right][\mathrm{Cl}]$} & {$\left[\mathrm{C}_{6} \mathrm{mim}\right][\mathrm{Cl}]$} & {$\left[\mathrm{C}_{8} \mathrm{mim}\right][\mathrm{Cl}]$} \\
\hline S.quadricauda & $20,50,100,150,200$ & $5,10,20,50,100$ & $1,5,10,20,40$ \\
C.vulgaris & $2,5,10,20,30,50$ & $2,5,10,30,50$ & $0.2,0.5,1,2,5,10$ \\
\hline
\end{tabular}

Experiments at each concentration were carried out in triplicate. The flasks were each plugged with a wad of cotton wool to protect the medium from contamination, then cultured on a shaker at $120 \mathrm{r} / \mathrm{min}$, at $26 \pm 1{ }^{\circ} \mathrm{C}$ at an illumination intensity of 56 $\pm 1 \mu \mathrm{mol} / \mathrm{m}^{2} / \mathrm{s}$ on a $12 \mathrm{~h}: 12 \mathrm{~h}$ light: dark cycle.

Aliquots were withdrawn from the cultures in a biosafety cabinet on the $0^{\text {th }}$ and $96^{\text {th }}$ hour of the experiment. The cultures were examined under a microscope over the entire course of the experiment, to ensure that no microbial contamination had taken place. 


\subsection{Flow cytometric analysis}

Flow cytometric analysis was performed using a BD Accuri ${ }^{\mathrm{TM}}$ C6 flow cytometer (Bectone Dickinson, USA) equipped with $488 \mathrm{~nm}$ and $640 \mathrm{~nm}$ argon lasers at a flow rate of $1 \mathrm{~mL} / \mathrm{s}$, as described in our previous report (Deng et al., 2015). Aggregated cells, non-algal particles and dead cells were excluded by gating in FSC-height/FSC-area diagrams and SSC/FL4 diagrams. Aliquots taken from the culture were filtered through a $48 \mu \mathrm{m}$ membrane filter and analysed by FCM to monitor cell density, membrane permeability, chlorophyll $a$ autofluorescence and FDA stained fluorescence. Cell density and chlorophyll $a$ autofluorescence were measured directly. Aliquots taken from the culture were stained with a solution of PI at $30 \mu \mathrm{mol} / \mathrm{L}$ for $S$. quadricauda and $20 \mu \mathrm{mol} / \mathrm{L}$ for $C$. vulgaris, then allowed to stand for $20 \mathrm{~min}$ at $25{ }^{\circ} \mathrm{C}$ in the dark. The concentrations of stain with FDA were $30 \mu \mathrm{mol} / \mathrm{L}$ for $S$. quadricauda and $25 \mu \mathrm{mol} / \mathrm{L}$ for $C$. vulgaris. The stained cells were then left to stand for 10 min. Autofluorescence data were collected using the FL4 channel (675 \pm $12 \mathrm{~nm}$ ), and fluorescence data from PI and FDA stained cells were collected using the FL2 $(585 \pm 20 \mathrm{~nm})$ and FL1 channels, $(533 \pm 15 \mathrm{~nm})$ respectively. The data were expressed as mean fluorescence intensities (MFIs).

\subsection{Data analysis}

The results collected in the reports represent mean values of triplicate samples. The inhibition rate $(I R)$ of each IL towards each alga was calculated using the 
equation:

$$
\operatorname{IR}(\%)=\left(1-\mu_{\mathrm{i}} / \mu_{\mathrm{c}}\right) \times 100 \%
$$

In which $I R$ is the inhibition rate, $\mu_{\mathrm{i}}$ and $\mu_{\mathrm{c}}$ are the growth rates of the sample and the control after the same incubation time, calculated using Equation (2):

$$
\mu=\left(\ln n_{L^{-}} \ln n_{0}\right) /\left(t_{L^{-}} t_{0}\right)
$$

in which $n_{0}$ is the initial cell density, $n_{L}$ is the cell density at time $t_{L}, t_{0}$ is the time of test start and $t_{L}$ is the time of sampling.

The $\mathrm{ErC}_{50}$ represents the concentration of toxicant that results in a $50 \%$ reduction in growth rate compared with the control after $96 \mathrm{~h}$ incubation time. The $\mathrm{ErC}_{50}$ values were calculated using Analyze-Regression Probit procedure in IBM SPSS (version 19.0; Armonk, NY, USA) (Li et al., 2015). The properties of cells exposed to different $C_{I L}$ were analysed using the One-way Analysis of Variance (ANOVA) procedure and Duncan's new multiple range test in POST HOC in IBM SPSS. $\mathrm{P} \leqslant 0.05$ is the criterion for significant difference.

\section{Results and discussion}

\subsection{Cell growth}

The cell densities plotted against time are depicted in Fig. 1 and the calculated 96 $\mathrm{h} \mathrm{ErC}_{50}$ values are reported in Table 2. Previous researchers have concluded that the "side-chain effect" is the main chemical factor determining the toxicity of ILs (Pham et al., 2010; Saraiva et al., 2017). In this study, the $\mathrm{ErC}_{50}$ value of ILs towards both species decreased with increasing length of the side chain, supporting this conclusion. 

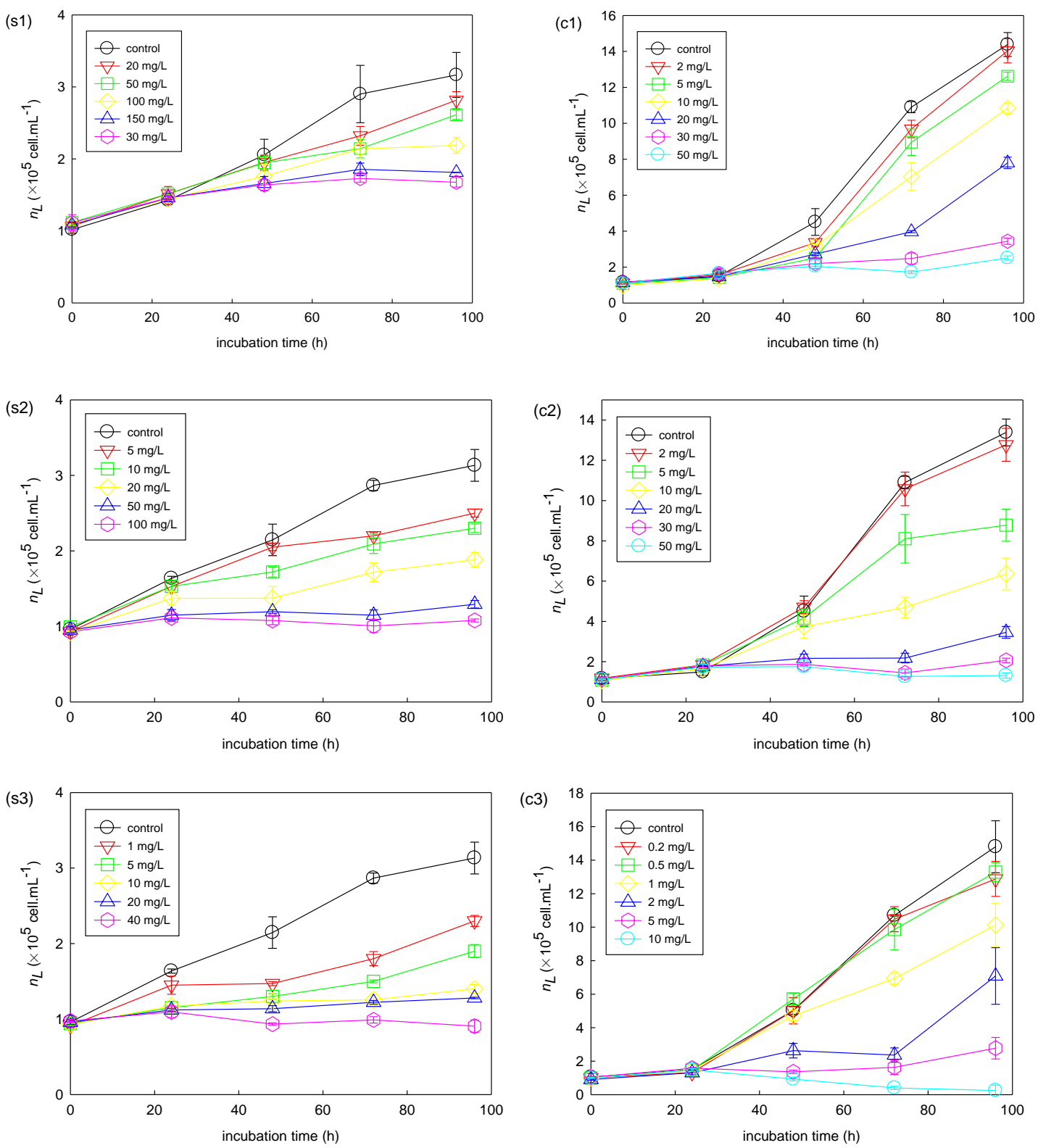

Fig. 1 Cell densities at different incubation time: (s1) $S$ quadricauda exposed to $\left[\mathrm{C}_{4} \mathrm{mim}\right][\mathrm{Cl}]$; (s2) $S$ quadricauda exposed to $\left[\mathrm{C}_{6} \mathrm{mim}\right][\mathrm{Cl}]$; (s3) $S$ quadricauda exposed to $\left[\mathrm{C}_{8} \mathrm{mim}\right][\mathrm{Cl}]$; (c1) C. vulgaris exposed to $\left[\mathrm{C}_{4} \mathrm{mim}\right][\mathrm{Cl}]$; (c2) C. vulgaris exposed to $\left[\mathrm{C}_{6} \mathrm{mim}\right][\mathrm{Cl}]$; (c3) C. vulgaris exposed to $\left[\mathrm{C}_{8} \mathrm{mim}\right][\mathrm{Cl}]$.

Table 2 The $96 \mathrm{~h}-\mathrm{ErC}_{50}$ values $(\mathrm{mg} / \mathrm{L})$ of $\left[\mathrm{C}_{\mathrm{n}} \mathrm{mim}\right][\mathrm{Cl}](\mathrm{n}=4,6,8)$ for S.quadricauda and C.vulgaris. 


\begin{tabular}{cccc}
\hline ILs & {$\left[\mathrm{C}_{4} \mathrm{mim}\right][\mathrm{Cl}]$} & {$\left[\mathrm{C}_{6} \mathrm{mim}\right][\mathrm{Cl}]$} & {$\left[\mathrm{C}_{8} \mathrm{mim}\right][\mathrm{Cl}]$} \\
\hline S.quadricauda & 129 & 22.3 & 5.60 \\
C.vulgaris & 32 & 16.2 & 3.90 \\
\hline
\end{tabular}

During the test period, the $\mathrm{ErC}_{50}$ values of each IL towards $C$. vulgaris were lower than those of $S$. quadricauda, suggesting that $C$. vulgaris is more sensitive than S. quadricauda (Table 2). Roubeix et al. (2011) also found that smaller species were more sensitive towards toxins. However, in another study, smaller species proved to be more tolerant (Ricart et al., 2009). This apparent paradox can be resolved if cell size is not, in fact, a determining factor in microalgal sensitivity.

$\left[\mathrm{C}_{4} \operatorname{mim}\right][\mathrm{Cl}]$ was used to study the toxic effect of $\left[\mathrm{C}_{n} \mathrm{mim}\right]$ ILs on the morphology of cells (Fig 2). For both species, MFI from the forward scatter channel $\left(M F I_{F S C}\right)$ and MFI from the side scatter channel $\left(M F I_{S S C}\right)$ increased, suggesting that the particle size and fine structural complexity increased. This phenomenon usually occurs because of increased cell size or cell deformation (Franqueira et al., 2000; Franklin et al., 2001). However, an alternative explanation for this change in scattering intensity may be the formation of a mucilaginous sheath around the algal cells, as a protective barrier against the IL (Nam et al., 2018).
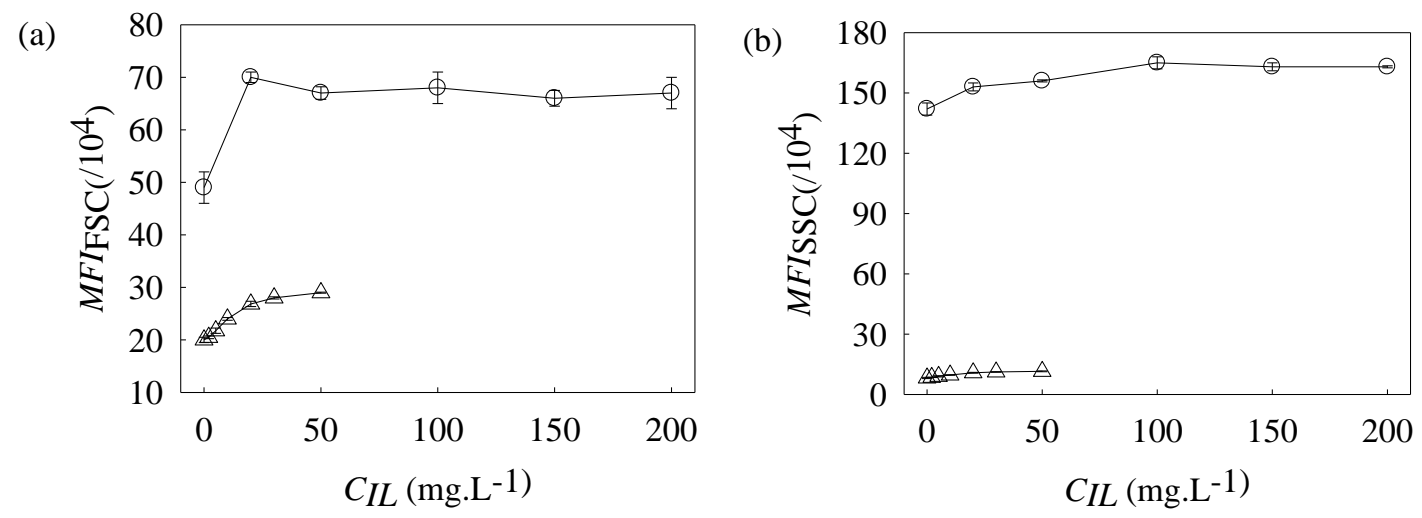
Fig 2 Effect of $\left[\mathrm{C}_{4} \mathrm{mim}\right][\mathrm{Cl}]$ on the morphology of algae after a $96 \mathrm{~h}$ exposure: $\circ, S$.

quadricauda; $\triangle$, C. vulgaris.

When $C_{I L}<50 \mathrm{mg} / \mathrm{L}$, the MFIs increased generally with $C_{I L}$. At $50 \mathrm{mg} / \mathrm{L}$, the $M F I_{F S C}$ of exposed S. quadricauda and C. vulgaris were $9.86 \%$ and $40.24 \%$ higher than the control, whilst the $M F I_{S S C}$ values were $36.73 \%$ and $45.00 \%$ higher, respectively. When $C_{I L} \mathrm{~S}$ were higher than $50 \mathrm{mg} / \mathrm{L}$, the MFIs did not increase further $(\mathrm{P}>0.05)$. These results suggest that both the cells' size and the complexity of their fine structure increased more for $C$. vulgaris than S. quadricauda. The disparity in cell size between the two algae became very obvious, with $C$. vulgaris cells enlarging by 4 times as much as those of $S$. quadricauda after exposure to the IL. The influence of $\left[\mathrm{C}_{6} \mathrm{mim}\right][\mathrm{Cl}]$ and $\left[\mathrm{C}_{8} \mathrm{mim}\right][\mathrm{Cl}]$ on the morphology of the cells showed similar tendencies, so no further investigation of these ILs was undertaken.

\subsection{Membrane permeability}

Because of its ability to penetrate damaged cellular membranes, the dye PI is frequently used to assess membrane integrity (cell viability) (Franklin et al., 2001). However, it is important to appreciate that uptake of PI is also observed in cells with intact membranes (healthy cells). Nevertheless, in a histogram of fluorescence intensity, healthy cells fluoresce in a region of lower fluorescence intensity, which is distinct and clearly separated from the region where dead cells fluoresce (Deng et al., 2015). In this study, we have used the MFI of cells stained with PI $\left(M F I_{P I}\right)$ as an indicator of membrane permeability, as permeability is proportional to the quantity of 
PI entering the cells.

From the results of ANOVA, after $96 \mathrm{~h}$ exposure, the $M F I_{P I}$ for both species started to increase from a certain value, which we have referred to as the 'threshold concentration' (TC) of exposed IL (Table 3). At $C_{I L}$ values lower than the TCs (Fig 3), the differences in membrane permeability for the samples were not statistically significant $(\mathrm{P}>0.05)$, compared with the control. At $C_{I L}$ values higher than the TCs, $M F I_{P I}$ increased in a concentration-dependent manner, indicating that membrane permeability had increased, and membrane integrity may have been compromised.

As shown in Table 3, S. quadricauda had a higher TC towards $\left[\mathrm{C}_{4} \mathrm{mim}\right][\mathrm{Cl}]$ than C. vulgaris. At $50 \mathrm{mg} / \mathrm{L}$ for $\left[\mathrm{C}_{6} \mathrm{mim}\right][\mathrm{Cl}]$ and at $10 \mathrm{mg} / \mathrm{L}$ for $\left[\mathrm{C}_{8} \mathrm{mim}\right][\mathrm{Cl}], M F I_{P I}$ increased by $51 \%$ and $42 \%$ for S. quadricauda, and by $210 \%$ and $220 \%$, respectively for $C$. vulgaris, compared with the control. The superior membrane resistance of $S$. quadricauda is probably a major factor in its reduced sensitivity towards ILs, compared with $C$. vulgaris. 
(s1)

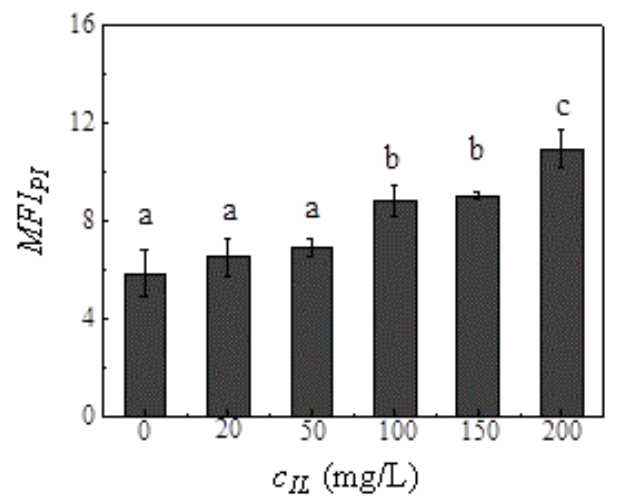

(s2)

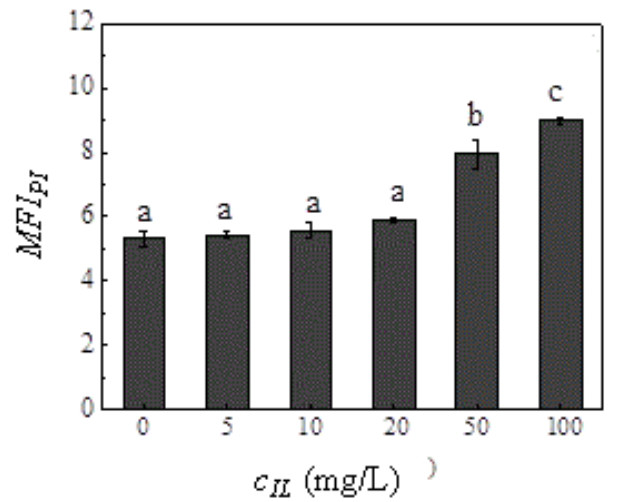

(s)

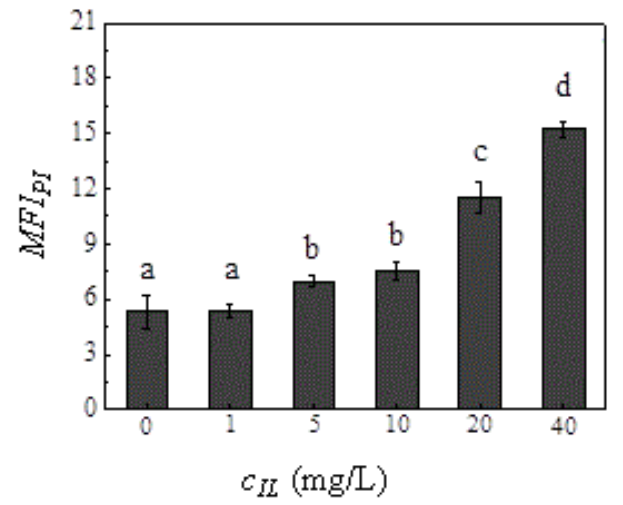

(c1)

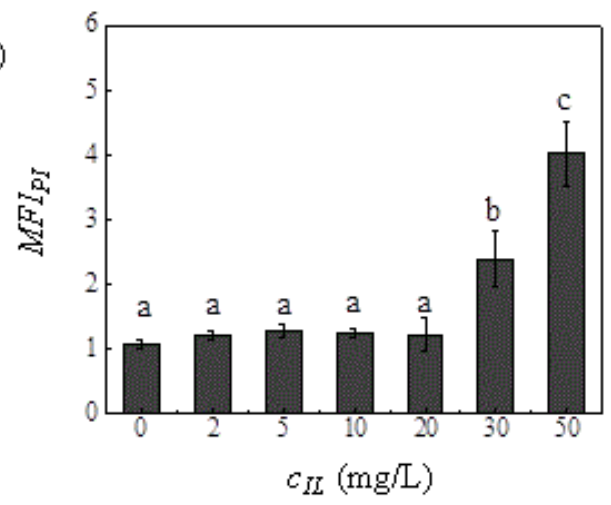

(c2)

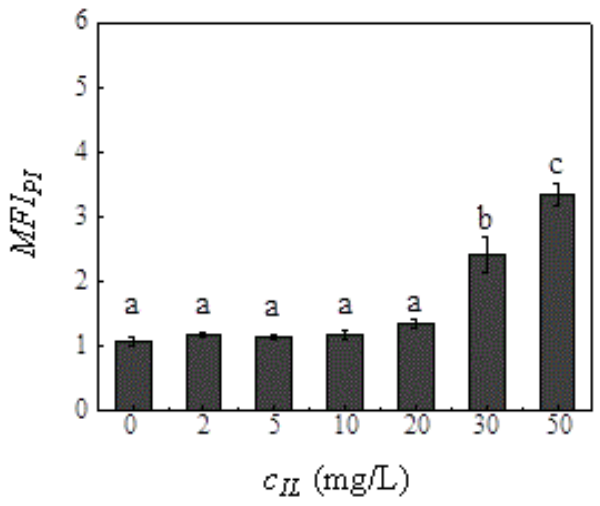

(c3)

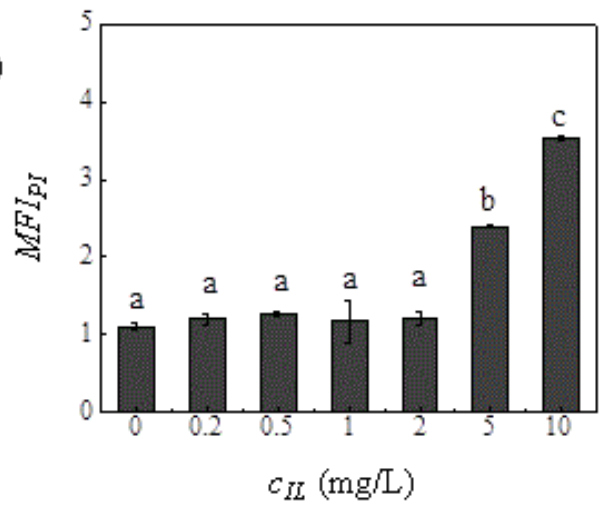

Fig. 3 MFI after staining with PI, reflecting cell permeability (graph numbers correspond to Fig. 1).

Note: The letters above the bars represent statistical differences: bars with the same letter have no statistical difference between them $(\mathrm{P}>0.05)$, whilst those with different letters exhibit statistical differences $(\mathrm{P}<0.05)$.

Table 3 The threshold concentration (TC) for membrane damage $(\mathrm{mg} / \mathrm{L})$ of $\left[\mathrm{C}_{\mathrm{n}} \operatorname{mim}\right][\mathrm{Cl}](\mathrm{n}=4,6,8)$ on $S$. quadricauda and C. vulgaris. 


\begin{tabular}{cccc}
\hline ILs & {$\left[\mathrm{C}_{4}\right.$ mim $][\mathrm{Cl}]$} & {$\left[\mathrm{C}_{6} \mathrm{mim}\right][\mathrm{Cl}]$} & {$\left[\mathrm{C}_{8} \mathrm{mim}\right][\mathrm{Cl}]$} \\
\hline S.quadricauda & $50-100$ & $20-50$ & $1-5$ \\
C.vulgaris & $20-30$ & $20-30$ & $2-5$ \\
\hline
\end{tabular}

\subsection{Chlorophyll $a$ content $\left(C_{C h l}\right)$}

$C_{C h l}$ is a good indicator of the physiological state of individual cells, as it provides information on metabolite absorption and distribution, as well as cellular energy use in preparation for photosynthesis (Hadjoudja et al., 2009; Cid et al., 1996). The MFI of chlorophyll $a$ fluorescence $\left(M F I_{C h l}\right)$ determined by FCM is proportional to the mean $C_{C h l}$ of each cell.

After $96 \mathrm{~h}$ exposure, the $M F I_{C h l}$ values of $S$. quadricauda exposed to $\left[\mathrm{C}_{\mathrm{n}} \mathrm{mim}\right][\mathrm{Cl}]$ $(\mathrm{n}=4,6,8)$ were generally reduced compared with the control (Fig 4). However, the inhibition effects were not obviously concentration-dependent, as the $M F I_{C h l}$ of cells exposed to $\left[\mathrm{C}_{4} \mathrm{mim}\right][\mathrm{Cl}]$ at all concentrations were statistically the same $(\mathrm{P}>0.05)$, as were those of cells exposed to $\left[\mathrm{C}_{6} \mathrm{mim}\right][\mathrm{Cl}]$ at $5-20 \mathrm{mg} / \mathrm{L}$. For $\left[\mathrm{C}_{6} \mathrm{mim}\right][\mathrm{Cl}]$ at $50-100$ $\mathrm{mg} / \mathrm{L}$ and $\left[\mathrm{C}_{8} \mathrm{mim}\right][\mathrm{Cl}]$ at all tested concentrations, the $M F I_{C h l}$ of cells decreased in a concentration-dependent manner. This inhibition in $C_{C h l}$ has been corroborated by several prior studies into the toxicity of $\left[\mathrm{C}_{\mathrm{n}} \mathrm{mim}\right]$-based ILs towards microalgae (Liu et al., 2015 c) and is thought to be induced by inhibition of electron flow on the donor side of the photosystem II (PS II) reaction centre (Franqueira et al., 2000). 
(s1)

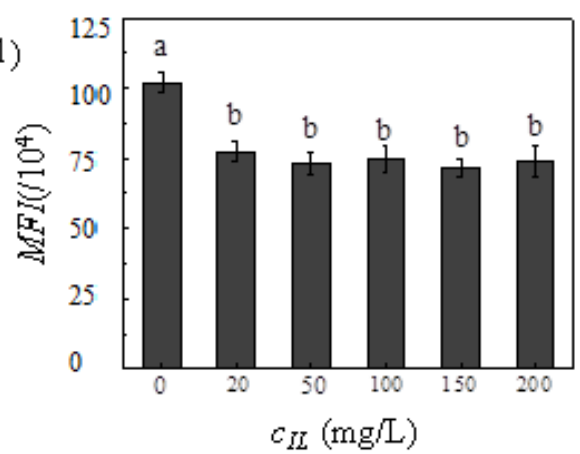

(s2)

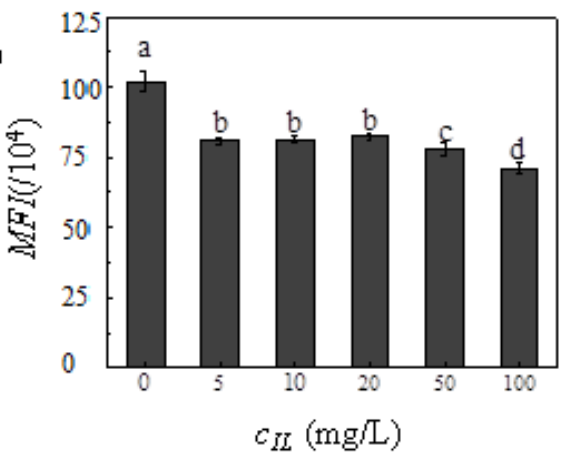

(s3)

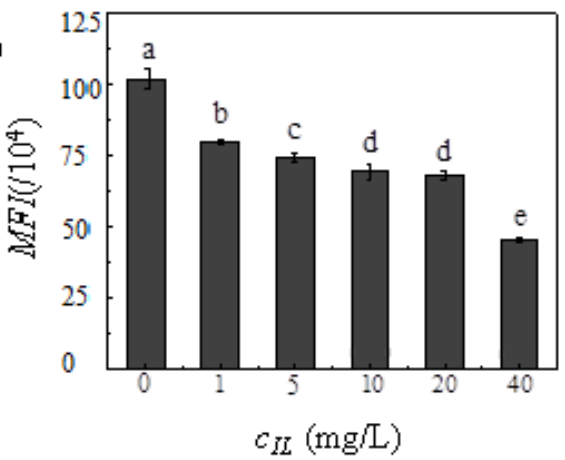

(c1)

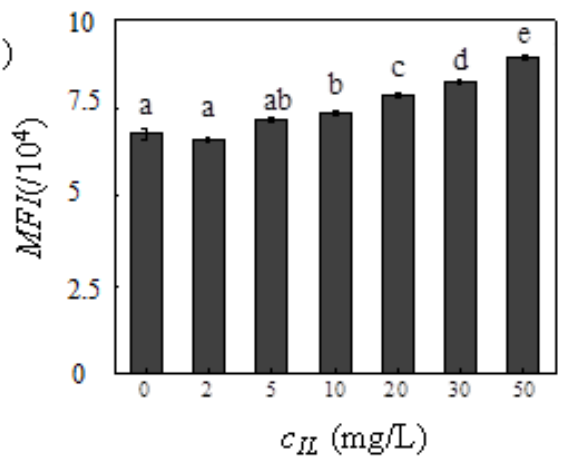

(c2)

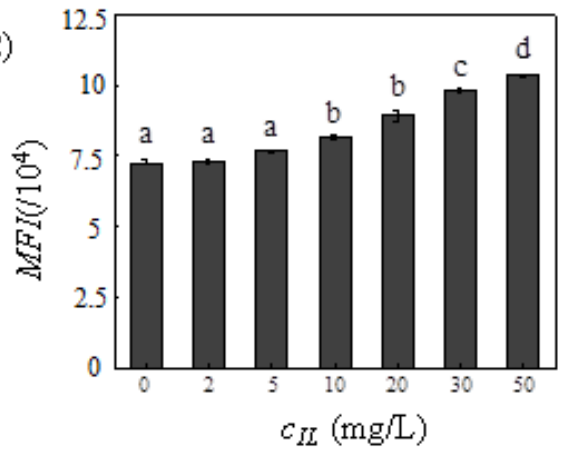

(c3)

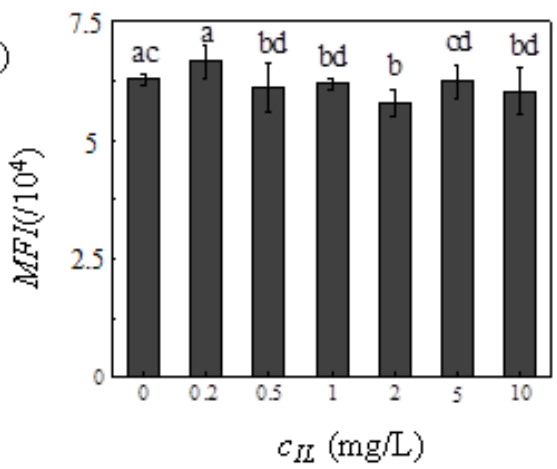

Fig. 4 Mean chlorophyll fluorescence of the samples exposed to different IL concentrations (graph numbers and notes correspond to Fig. 3).

The response of $C$. vulgaris towards the ILs was clearly different from that of $S$. quadricauda. For $\left[\mathrm{C}_{4} \mathrm{mim}\right][\mathrm{Cl}]$ and $\left[\mathrm{C}_{6} \mathrm{mim}\right][\mathrm{Cl}]$ at $2-5 \mathrm{mg} / \mathrm{L}$ and for $\left[\mathrm{C}_{8} \mathrm{mim}\right][\mathrm{Cl}]$ at $0.2 \mathrm{mg} / \mathrm{L}$, the $M F I_{C h l}$ values for the cells were statistically the same as for the control 
(P>0.05). However, for $\left[\mathrm{C}_{4} \mathrm{mim}\right][\mathrm{Cl}]$ and $\left[\mathrm{C}_{6} \mathrm{mim}\right][\mathrm{Cl}]$ at $10-50 \mathrm{mg} / \mathrm{L}$, the $M F I_{C h l}$ of the cells increased with $C_{I L}$ by $10.4 \%-62.9 \%$, compared with the control. These results suggest that the ILs tested cannot be inhibiting Chl $a$ synthesis in algal cells. When the $\left[\mathrm{C}_{8} \mathrm{mim}\right][\mathrm{Cl}]$ concentration was higher than $0.2 \mathrm{mg} / \mathrm{L}$, the $M F I_{C h l}$ was inhibited in a non-concentration-dependent manner, with a maximum inhibition of $5.4 \%$.

Previous studies have demonstrated that the $C_{C h l}$ of algae can actually increase when they are exposed to imidazolium-based ILs, metal ions (eg. vanadium, cobalt, copper) or other organic chemicals (eg. 3-(3,4-dichlorophenyl)-1,1-dimethylurea, 2-benzoxazolinone, carbamazepine) (Tsarpali et al., 2016). This $C_{C h l}$ increase can be explained by an inhibition of electron flow on the acceptor side of the PS II reaction centre (Franqueira et al., 2000).

It has even been suggested that an increase in $C_{C h l}$ occurs as part of a protective mechanism during phototropic algal growth, although the exact mechanism remains unknown (Tsarpali et al., 2016). Some microalgae have been shown to secrete phytohormones when exposed to toxins (Debenest et al., 2010), and some exogenously applied phytohormones can stimulate $C_{C h l}$ in $C$. vulgaris (Meisch et al., 1975). C. vulgaris exposed to $\left[\mathrm{C}_{6} \mathrm{mim}\right][\mathrm{Cl}]$ might also be expected to secrete phytohormones as a response to metabolic stress from an IL, resulting in a corresponding increase in $C_{C h l}$. However, in this study there was no indication to support such a hypothesis. On the contrary, C. vulgaris displayed a lower tolerance towards ILs (reflected in lower $\mathrm{ErC}_{50}$ values) than did S. quadricauda, suggesting that 
no such protective response had occurred, or if it had, then its effect on sensitivity was negligible.

On the other hand, it has also been proposed that in certain photoautotrophic organisms, in the absence of cell division, chlorophyll synthesis is the major biochemical imperative (Hagen et al., 2001). In such organisms, an increase in $C_{C h l}$ would naturally be expected to accompany any inhibition of cell division. As the cell division of $C$. vulgaris was inhibited more significantly than that of $S$. quadricauda, such a transformation of biochemical imperative might provide a possible explanation for the increased $C_{C h l}$.

\subsection{Esterase activity}

FDA is not itself a dye, but exhibits a green fluorescence after hydrolysis by nonspecific esterases within living cells. As a result, the MFI emitted by FDA stained cells $\left(M F I_{F D A}\right)$ is commonly used as a rapid and sensitive technique to assess phytoplankton metabolic activity (Prado et al., 2012).

After $96 \mathrm{~h}$ exposure, $\left[\mathrm{C}_{4} \mathrm{mim}\right][\mathrm{Cl}]$ at all concentrations, as well as $\left[\mathrm{C}_{6} \mathrm{mim}\right][\mathrm{Cl}]$ at $5 \mathrm{mg} / \mathrm{L}-20 \mathrm{mg} / \mathrm{L}$ and $\left[\mathrm{C}_{8} \mathrm{mim}\right][\mathrm{Cl}]$ at $1 \mathrm{mg} / \mathrm{L}-10 \mathrm{mg} / \mathrm{L}$, respectively inhibited the $M F I_{F D A}$ of $S$. quadricauda (Fig 5). Nevertheless, the relationship between the inhibition effects and $C_{I L}$ was not as simple as might be expected. Among the cells exposed to different concentrations of $\left[\mathrm{C}_{4} \mathrm{mim}\right][\mathrm{Cl}]$, the statistical differences were not significant $(\mathrm{P}>0.05)$. Moreover, the $M F I_{F D A}$ of the $S$. quadricauda cells exposed to $\left[\mathrm{C}_{6} \mathrm{mim}\right][\mathrm{Cl}]$ and especially $\left[\mathrm{C}_{8} \mathrm{mim}\right][\mathrm{Cl}]$ increased with $C_{I L}$, instead of decreasing. At 
50-100 $\mathrm{mg} / \mathrm{L}$ exposure to $\left[\mathrm{C}_{6} \mathrm{mim}\right][\mathrm{Cl}]$ (an $\mathrm{IL}$ of relatively high lipophilicity) did not give rise to statistically significant differences compared with the control $(\mathrm{P}>0.05)$. However, at $40 \mathrm{mg} / \mathrm{L}$ the most lipophilic $\mathrm{IL},\left[\mathrm{C}_{8} \mathrm{mim}\right][\mathrm{Cl}]$ had a significant effect, enhancing $M F I_{F D A}$ by $59.6 \%$ compared with the control.

(s1)

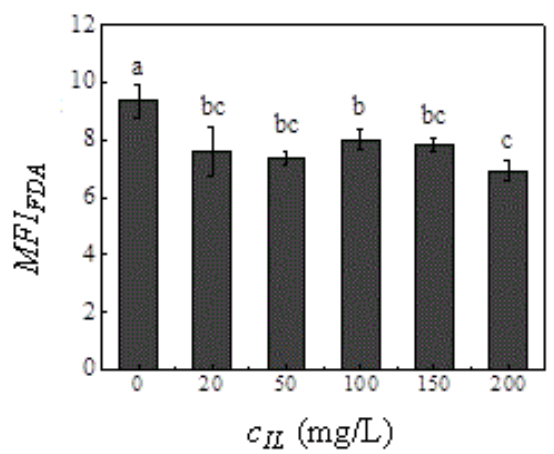

(s2)

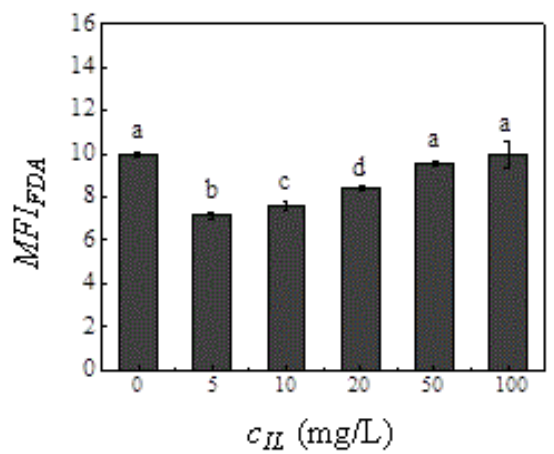

(s3)

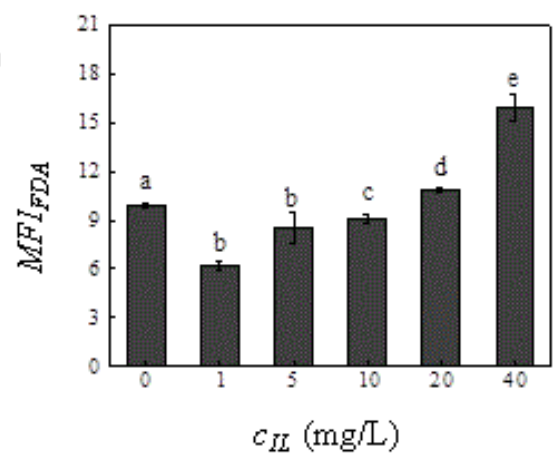

(c1)

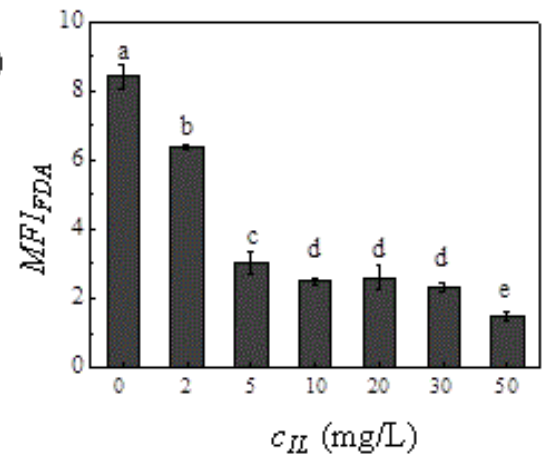

(c2)

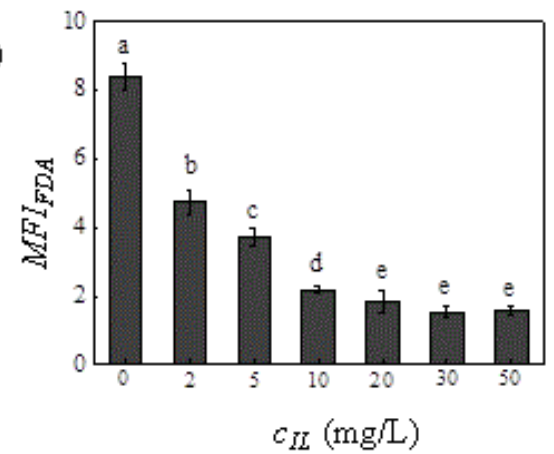

(c3)

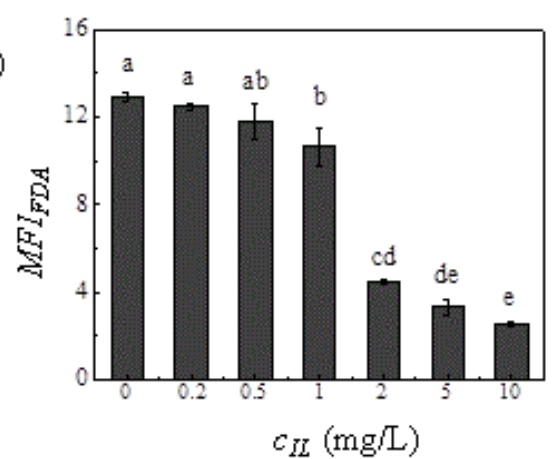

Fig. 5 MFI after staining with FDA, reflecting esterase activity (graph numbers and notes correspond to Fig. 3).

Most studies conclude that an increase in $M F I_{F D A}$ is a result of greater esterase activity, which in turn reflects an activation and upregulation of detoxification 
processes (Jamers et al., 2009; Sogorb et al., 2002). Many lipophilic toxins, such as herbicides and pesticides, are metabolized to give more polar molecules for easier expulsion in aqueous media. The most effective way to convert a lipophilic ester into water-soluble products is for it to undergo hydrolysis to the corresponding alcohol and carboxylic acid, catalyzed by an esterase enzyme. The resulting alcohol and acid metabolites are much more water-soluble as a result of effective hydrogen-bonding and often have lower toxicity. The biodegradation of $\left[\mathrm{C}_{\mathrm{n}} \mathrm{mim}\right] \mathrm{ILs}$, which do not contain esters, has been proposed to rely on oxidative metabolism, rather than hydrolysis (Docherty et al., 2007; Stolte et al., 2008). However, the marked increase in esterase activity with increasing $C_{I L}$ may have occurred as part of a generalized metabolic response, which does not require the presence of an ester in the ILs.

Alternatively, the $M F I_{F D A}$ increase may merely reflect an increase in FDA uptake, which is expected to occur as a result of greater membrane permeability (Hampel et al., 2001; Franklin et al., 2001), Fig 3 (s2 and s3). Moreover, an increase in intracellular $\mathrm{pH}$ (another defensive mechanism) mediated by intracellular ionic regulation may also play a part in the increase in $M F I_{F D A}$ (Hadjoudja et al., 2009).

The response of $C$. vulgaris was more straightforward. Except in the case of $\left[\mathrm{C}_{8} \mathrm{mim}\right][\mathrm{Cl}]$, at $0.2-0.5 \mathrm{mg} / \mathrm{L}, C$. vulgaris did not show any statistical differences from the control. However, for $\left[\mathrm{C}_{4} \mathrm{mim}\right][\mathrm{Cl}]$ and $\left[\mathrm{C}_{6} \mathrm{mim}\right][\mathrm{Cl}]$ at all other concentrations, as well as $\left[\mathrm{C}_{8} \mathrm{mim}\right][\mathrm{Cl}]$ at $1 \mathrm{mg} / \mathrm{L}-10 \mathrm{mg} / \mathrm{L}$, the $M F I_{F D A}$ had decreased, indicating that the metabolic activity of the cells was compromised. The esterase activities of cells exposed to $\left[\mathrm{C}_{\mathrm{n}} \mathrm{mim}\right][\mathrm{Cl}]$ at $2 \mathrm{mg} / \mathrm{L}$ were $75.8 \%, 56.4 \%$ and $35.1 \%$ 
compared with the control, for $\left[\mathrm{C}_{\mathrm{n}} \mathrm{mim}\right] \mathrm{s}$ with $\mathrm{n}=4,6,8$ respectively. The inhibition increased in an IL-concentration dependent manner, reflecting the way $C$. vulgaris responds to toxic challenge by copper (Hadjoudja et al., 2009).

The presence of a more effective metabolic response, exemplified by increased esterase activity, may be a contributing factor in the greater tolerance of ILs exhibited by $S$. quadricauda, compared with $C$. vulgaris.

\section{Conclusions}

The toxic effects of $\left[\mathrm{C}_{\mathrm{n}} \operatorname{mim}\right][\mathrm{Cl}](\mathrm{n}=4,6,8)$ toward the same algae follow similar trends. As expected, a decrease in the concentration of IL required to induce toxic effects is observed as the IL alkyl chain is extended. Although $C$. vulgaris and $S$. quadricauda are both freshwater green algae with cell walls, their biochemical responses towards the ILs, such as Chl $a$ synthesis and esterase activity are different.

After exposure to the ILs, cell proliferation of both species was inhibited, and cell size, complexity, and membrane permeability increased. The toxic effects of the ILs toward C. vulgaris were more serious than those experienced by $S$. quadricauda. The $\mathrm{ErC}_{50}$ values towards S. quadricauda and C. vulgaris ranged from $5.60-129$ $\mathrm{mg} / \mathrm{L}$ and $3.90-32 \mathrm{mg} / \mathrm{L}$, respectively. At the same $C_{I L}, M F I_{P I}$ for $S$. quadricauda increased more than for $C$. vulgaris. Inhibition of $\mathrm{Chl} a$ synthesis was observed for $S$. quadricauda, whilst Chl $a$ synthesis was induced in C. vulgaris, possibly from a reprioritisation of the biochemical imperative, accompanying inhibition of cell division. For $C$. vulgaris, the $M F I_{F D A}$ results after exposure to most IL doses indicated 
that esterase inhibition had occurred compared with the control, demonstrating that metabolic activity was compromised. The inhibitory effects in C. vulgaris occurred in an IL-concentration dependent manner, consistent with exposure to a lipophilic toxin. The effect of IL exposure on S. quadricauda metabolism was completely opposite, resulting in a notable induction of esterase activity with increasing $C_{I L}$, especially at higher doses.

In conclusion, evidence suggests that membrane resistance and a possible metabolic response resulting in enzyme induction, give rise to the lower sensitivity of S. quadricauda towards ILs, compared with C. vulgaris. This intriguing finding merits larger-scale studies (sample size $\geq 40$ ) that will inform future ERA research into the environmental risk posed by ionic liquids in the environment.

\section{Acknowledgements}

This work was supported by the Fundamental Research Funds for the Central Universities (No. JUSRP11521) and by the Open Funds of Jiangsu Key Laboratory of Anaerobic Biotechnology (No.JKLAB2017112).

\section{References:}

Abramenko, N., Kustov, L., Metelytsia, L., Kovalishyn, V., Tetko, I., Peijnenburg, W., 2020. A review of recent advances towards the development of QSAR models for toxicity assessment of ionic liquids, J.

Hazard. Mater. 384, 121429-121429. 
Barron, M. G., Jackson, C. R., Awkerman, J. A., 2012. Evaluation of in silico development of aquatic toxicity species sensitivity distributions. Aquat. Toxicol. 116, 1-7.

Bubalo, M. C., Radosevic, K., Redovnikovic, I. R., Halambek, J., Srcek, V. G., 2014. A brief overview of the potential environmental hazards of ionic liquids. Ecotoxicol. Environ. Saf. 99, 1-12.

Chatel, G., Naffrechoux, E., Draye, M., 2017. Avoid the PCB, mistakes: A more sustainable future for ionic liquids. J. Hazard. Mater. 324, 773-780.

Chen, H., Zou, Y., Zhang, L., Wen, Y., Liu, W., 2014. Enantioselective toxicities of chiral ionic liquids 1-alkyl-3-methylimidazolium lactate to aquatic algae, Aquat. Toxicol. 154, 114-120.

Cid, A., Fidalgo, P., Herrero, C., Abalde, J., 1996. Toxic action of copper on the membrane system of a marine diatom measured by flow cytometry. Cytometry 25, 32-36.

Costa, S. P. F., Azevedo, A. M. O., Pinto, P. C. A. G., Saraiva, M. L. M. F. S., 2017. Environmental impact of ionic liquids: recent advances in (eco)toxicology and (bio)degradability. ChemSusChem 10, 2321-2347.

Debenest, T., Gagne, F., Petit, A. N., Kohli, M., Eullafroy, P., Blaise, C., 2010. Monitoring of a flame retardant (tetrabromobisphenol A) toxicity on different microalgae assessed by flow cytometry. J. Environ. Monit. 12, 1918-1923.

Deng, Y., Beadham, I., Wu, J., Chen, X.-D., Hu, L., Gu, J., 2015. Chronic effects of the ionic liquid $\mathrm{C}_{4}$ mim $\mathrm{Cl}$ towards the microalga Scenedesmus quadricauda. Environ. Pollut. 204, 248-255.

Docherty, K. M., Dixon, J. K., Kulpa, Jr C. F., 2007. Biodegradability of imidazolium and pyridinium ionic liquids by an activated sludge microbial community. Biodegradation 18, 481-493. 
Franklin, N. M., Adams, M. S., Stauber, J. L., Lim, R. P., 2001. Development of an improved rapid enzyme inhibition bioassay with marine and freshwater microalgae using flow cytometry. Arch. Environ. Contam. Toxicol. 40, 469-480.

Franqueira, D., Orosa, M., Torres, E., Herrero, C., Cid, A., 2000. Potential use of flow cytometry in toxicity studies with microalgae. Sci. Total Environ. 247, 119-126.

Habibul, N., Ilmurat, M., Habibul, Z., Hu, Y., Ma, X., 2020. Uptake and accumulation of imidazolium ionic liquids in rice seedlings: Impacts of alkyl chain length, Chemosphere 242, 125228-125228.

Hampel, M., Moreno-Garrido, I., Sobrino, C., Lubian, L. M., Blasco, J., 2001. Acute toxicity of LAS homologues in marine microalgae: Esterase activity and inhibition growth as endpoints of toxicity, Ecotoxicol. Environ. Saf. 48, 287-292.

Hadjoudja, S., Vignoles, C., Deluchat, V., Lenain, J. F., Le Jeune, A. H., .Baudu, M., 2009. Short term copper toxicity on Microcystis aeruginosa and Chlorella vulgaris using flow cytometry. Aquat. Toxicol. $94,255-264$.

Hagen, C., Grunewald, K., Xylander, M., Rothe, E., 2001. Effect of cultivation parameters on growth and pigment biosynthesis in flagellated cells of Haematococcus pluvialis. J. Appl. Phycol. 13, 79-87.

$\mathrm{Hu}, \mathrm{X} ., \mathrm{Li}, \mathrm{J} ., \mathrm{Li}, \mathrm{C} ., 2$ 2013. Acute toxicity of selected imidazolium ionc liquids to Scenedesmus obliquus and QSAR study. Fresen. Environ. Bull. 22, 2498-2503.

Jamers, A., Lenjou, M., Deraedt, P., Van Bockstaele, D., Blust, R., de Coen, W., 2009. Flow cytometric analysis of the cadmium-exposed green alga Chlamydomonas reinhardtii (Chlorophyceae). Eur. J. Phycol. 44, 541-550.

Kulacki, K. J., Lamberti, G. A., 2008. Toxicity of imidazolium ionic liquids to freshwater algae. Green Chem. 10, 104-110. 
Liu, T., Zhu, L., Wang, J., Zhang, J., Sun, X., Zhang, C., 2015 a. Biochemical toxicity and DNA damage of imidazolium-based ionic liquid with different anions in soil on Vicia faba seedlings. Sci. Rep. 5, 18444.

Liu, H., Zhang, X., Chen, C., Du, S., Dong, Y., 2015 b. Effects of imidazolium chloride ionic liquids and their toxicity to Scenedesmus obliquus. Ecotox. Environ. Saf. 122, 83-90.

Liu, H., Zhang, X., Dong, Y., Chen, C., Zhu, S., Ma, X., 2015 c. Enantioselective toxicities of chiral ionic liquids 1-alkyl-3-methyl imidazolium tartrate on Scenedesmus obliquus. Aquat. Toxicol. 169, $179-187$.

Ma, J.M., Cai, L.L., Zhang, B.J., Hu, L.W., Li, X.Y., Wang, J.J., 2010. Acute toxicity and effects of 1-alkyl-3-methylimidazolium bromide ionic liquids on green algae. Ecotox. Environ. Saf. 73, 1465-1469.

Matzke, M., Stolte, S., Thiele, K., Juffernholz, T., Arning, J., Ranke, J., Welz-Biermann, U., Jastorff, B., 2007. The influence of anion species on the toxicity of 1-alkyl-3-methylimidazolium ionic liquids observed in an (eco) toxicological test battery. Green Chem. 9, 1198-1207.

Meisch, H. U., Bielig, H. J., 1975. Effect of vanadium on growth, chlorophyll formation and iron metabolism in unicellular green algae. Arch. Microbiol. 105, 77-82.

Mena, I. F., Diaz, E., Palomar, J., Rodriguez, J. J., Mohedano, A. F., 2020. Cation and anion effect on the biodegradability and toxicity of imidazolium- and choline-based ionic liquids. Chemosphere 240, 124947.

Moro, C. V., Bricheux, G., Portelli, C., Bohatier., J., 2012. Comparative effects of the herbicides chlortoluron and mesotrione on freshwater microalgae. Environ. Toxical. Chem. 31, 778-786. 
Nam, S.H., Kwak, J. I., An, Y.J., 2018. Quantification of silver nanoparticle toxicity to algae in soil via photosynthetic and flow-cytometric analyses. Sci. Rep. 8, 292-304.

Park, T.J., Lee, J.H., Lee, M.S., Park, C.H., Lee, C.H., Moon, S.D., Chung, J., Cui, R., An, Y.J., Yeom, D.H., Lee, S.H., Lee, J.K., Zoh, K.D., 2018. Development of water quality criteria of ammonia for protecting aquatic life in freshwater using species sensitivity distribution method. Sci. Total Environ. 634, 934-940.

Petkovic, M., Seddon, K. R., Rebelo, L. P. N., Pereira, C. S., 2011. Ionic liquids: a pathway to environmental acceptability, Chem. Soc. Rev 40, 1383-1403.

Pham, T. P. T., Cho, C.W., Yun, Y.S., 2010. Environmental fate and toxicity of ionic liquids: a review. Water Res. 44, 352-372.

Prado, R., Rioboo, C., Herrero, C., Suarez-Bregua, P., Cid, A., 2012. Flow cytometric analysis to evaluate physiological alterations in herbicide-exposed Chlamydomonas moewusii cells. Ecotoxicology 21, 409-420.

Ricart, M., Barcelo, D., Geiszinger, A., Guasch, H., Lopez de Alda, M., Romani, A. M., Vidal, G., Villagrasa, M., Sabater, S., 2009. Effects of low concentrations of the phenylurea herbicide diuron on biofilm algae and bacteria. Chemosphere 76, 1392-1401.

Roubeix, V., Mazzella, N., Schouler, L., Fauvelle, V., Morin, S., Coste, M., Delmas, F., Margoum, C., 2011. Variations of periphytic diatom sensitivity to the herbicide diuron and relation to species distribution in a contamination gradient: implications for biomonitoring. J. Environ. Monit. 13, $1768-1774$.

Sogorb, M. A., Vilanova, E., 2002. Enzymes involved in the detoxification of organo- phosphorus, carbamate and pyrethroid insecticides through hydrolysis. Toxicol. Lett. 128, 215-228. 
Stolte, S., Abdulkarim, S., Arning, J., Blomeyer-Nienstedt, A.-K., Bottin-Weber, U., Matzke, M., Ranke, J., Jastorff, B., Thoeming, J., 2008. Primary biodegradation of ionic liquid cations, identification of degradation products of 1-methyl-3-octylimidazolium chloride and electrochemical wastewater treatment of poorly biodegradable compounds. Green Chem. 10, 214-224.

Stulik, K., Amatore, C., Holub, K., Marecek, V., Kutner, W., 2000. Microelectrodes. Definitions, characterization, and applications (Technical Report). Pure Appl. Chem. 72, 1483-1492.

Thamke, V. R., Tapase, S. R., Kodam, K. M., 2017. Evaluation of risk assessment of new industrial pollutant, ionic liquids on environmental living systems. Water Res. 125, 237-248.

Tsarpali, V., Harbi, K., Dailianis, S., 2016. Physiological response of the green microalgae Dunaliella tertiolecta against imidazolium ionic liquids bmim $\mathrm{BF}_{4}$ and/or omim $\mathrm{BF}_{4}$ : the role of salinity on the observed effects. J. Appl. Phycol. 28, 979-990.

Wen, J., Cui, X., Gibson, M., Li, Z., 2018. Water quality criteria derivation and ecological risk assessment for triphenyltin in China. Ecotox. Environ. Safe 161, 397-401.

Zhang, L., Wei, C., Zhang, H., Song, M., 2017. Criteria for assessing the ecological risk of nonylphenol for aquatic life in Chinese surface fresh water. Chemosphere 184, 569-574. 